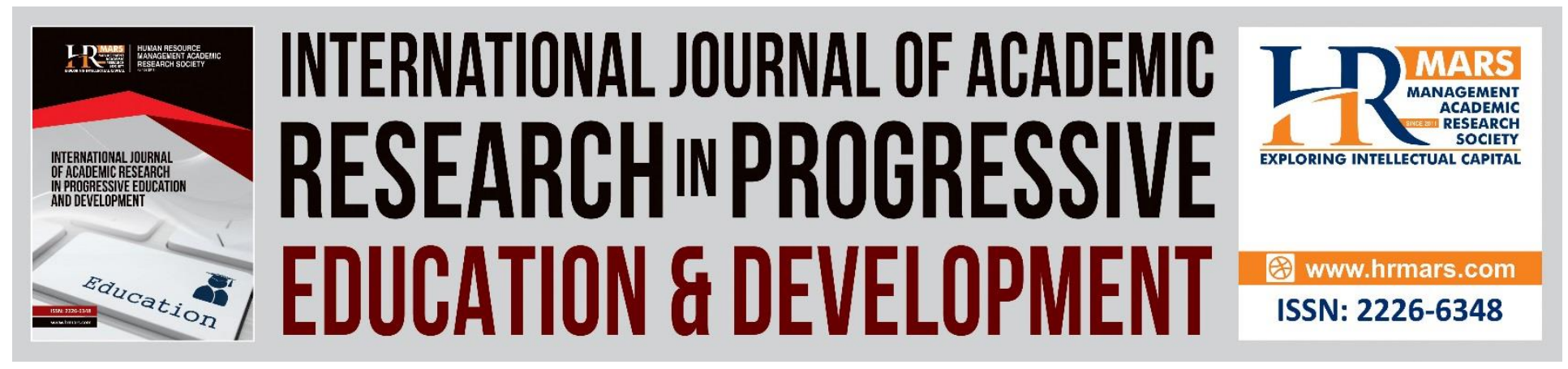

\title{
English Teaching Efficacy Enhancement Module (MPEBI) For Early Childhood Education Teachers: Measuring Its Validity Through Experts Viewpoints
}

\section{Nur Nazuha Beevi Abdul Aziz and Nordin Mamat}

To Link this Article: http://dx.doi.org/10.6007/IJARPED/v7-i4/5381

DOI: $10.6007 /$ IJARPED/v7-i4/5381

Received: 24 Nov 2018, Revised: 29 Dec 2018, Accepted: 03 Jan 2019

Published Online: 10 Jan 2019

In-Text Citation: (Aziz \& Mamat, 2018)

To Cite this Article: Aziz, N. N. B. A., \& Mamat, N. (2018). English Teaching Efficacy Enhancement Module (MPEBI) For Early Childhood Education Teachers: Measuring Its Validity Through Experts Viewpoints. International Journal of Academic Research in Progressive Education and Development, 7(4), 447-458.

\section{Copyright: (C) 2018 The Author(s)}

Published by Human Resource Management Academic Research Society (www.hrmars.com)

This article is published under the Creative Commons Attribution (CC BY 4.0) license. Anyone may reproduce, distribute, translate and create derivative works of this article (for both commercial and non-commercial purposes), subject to full attribution to the original publication and authors. The full terms of this license may be seen at: http://creativecommons.org/licences/by/4.0/legalcode

Vol. 7, No. 4, 2018, Pg. 447 - 458

Full Terms \& Conditions of access and use can be found at http://hrmars.com/index.php/pages/detail/publication-ethics 


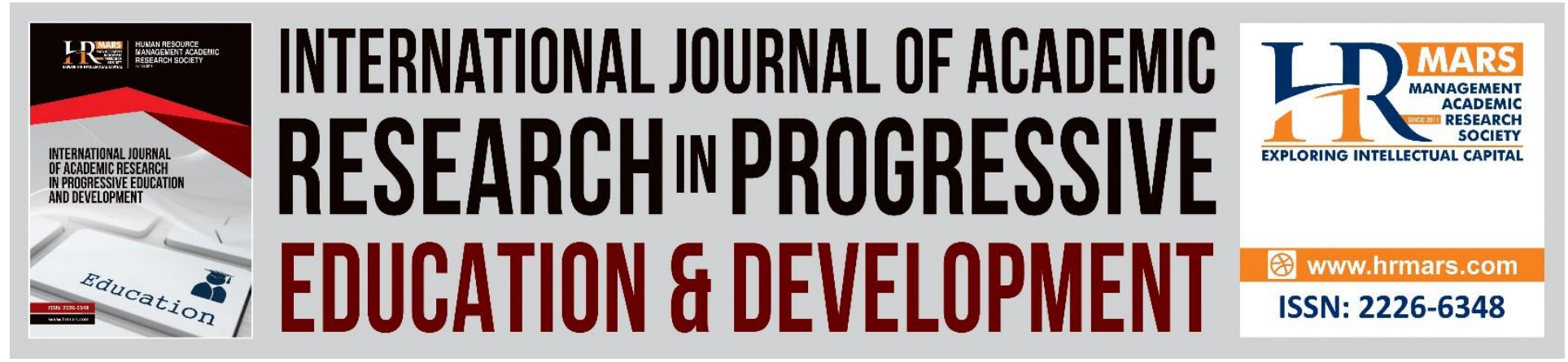

\title{
English Teaching Efficacy Enhancement Module (MPEBI) For Early Childhood Education Teachers: Measuring Its Validity Through Experts Viewpoints
}

\author{
Nur Nazuha Beevi Abdul Aziz ${ }^{1}$ and Nordin Mamat ${ }^{2}$ \\ National Child Development Research Centre, Faculty of Education and Human Development \\ Sultan Idris Education University, 35900, Tanjong Malim, Perak, Malaysia
}

\begin{abstract}
The study aims to evaluate the validity of the English Teaching Efficacy Enhancement Module (MPEBI) for Early Childhood Education Teachers that has been developed based on Bandura's Self-Efficacy Theory. In Bandura's Self-Efficacy Theory there are four main components that may influence efficacy which are past experience and knowledge, observation of other people's teaching, evaluation of the teaching and physiological as well as emotional changes. The module draft consists of six strategies: Strategy 1: Introduction, Strategy 2: Knowledge and Achievement in English, Strategy 3: Self-Modeling in Teaching, Strategy 4: Self-Assessment in Teaching, Strategy 5: Self-Emotion Development and Strategy 6: Closing-Self Transformation. A complete draft needs to undergo content validation process by the field experts and the module development experts. The two Validity Questionnaires developed by the researcher were the Content Validity Questionnaire for the English Teaching Efficacy Enhancement Module (MPEBI) for Early Childhood Education Teachers based on Russell (1974) and the Validity Questionnaire for the Content, Appropriate Strategy and Activity of the English Teaching Efficacy Enhancement Module (MPEBI) for Early Childhood Education Teachers based on Mohammad Aziz Shah (2010). The findings show that the English Teaching Efficacy Enhancement Module (MPEBI) has high content validity value.

Keywords: Module Content Validity, Module Draft, Questionnaires of Module Validity, Module Development Experts and English Teaching Efficacy Enhancement Module (MPEBI) for Early Childhood Education Teachers.
\end{abstract}

\section{Introduction}

English Teaching Efficacy Enhancement Module (MPEBI) for Early Childhood Education Teachers is a training module aimed at enhancing the level of efficacy of early childhood education teachers in teaching English. This is in line with some of the curriculum changes that have taken place in the teaching of English in our country. In 2010, there was a significant change 
DEVELOPMENT

Vol. 7, No. 4, 2018, E-ISSN: 2226-6348 @ 2018 HRMARS

in the teaching period of the English Language in the National Preschool Standard Curriculum (KSPK) in which English teaching is taught for 600 minutes per week (National Preschool Standard Curriculum, 2010). The Ministry of Education has implemented the Upholding the Malay Language and Strengthening Command of English (MBMMBI) to replace the Teaching and Learning of Science and Mathematics in English (PPSMI). This English strengthening programme is implemented with the realisation that English is the language of communication that young people need to master in order to compete both at national and global levels.

Then, Literacy and Numeracy Screening (LINUS) was introduced. Known as a programme created to enhance the mastery of literacy and numeracy among students, LINUS 2.0 was launched in 2013. The programme includes Basic Literacy in English which aims to help students master English. Through this programme, pupils with English literacy problem will receive additional help and support to enable them to be equivalent to the mainstream students. Quite recently, the 'Common European Framework of References' (CEFR) Course has been implemented since 2016 aiming at improving the quality and standard of English language teaching which is in line with international standards and supported by a quality implementation system. With these series of changes in the Malaysian education system in relation with English teaching and learning, the development of this module is an effort attempting to assist the early preschool teachers and the early childhood education teachers (of which English Language is not their teaching option) to be proficient in teaching English. (Nur Nazuha Beevi Abdul Aziz \& Nordin Mamat, 2018).

\section{Research Background}

The construction of complete module activities should include validity testing, so that the activities in the module really help the module users to master the stated objectives. Among important aspects to be taken into account in determining a module validity is to identify whether the activities are appropriate for the target population, effective and practical (Russell, 1974). However, the most important process in determining the validity of a module is during the module execution in which feedback or responses of the module users may be observed.

Determining the validity of a module is not easy as some of the activities are abstract. To measure the validity of an instrument or a module, Mohd. Majid Konting (2004) suggests experts' views are obtained. Therefore, in order to determine the content validity of the English Teaching Efficacy Enhancement Module (MPEBI) for Early Childhood Education Teachers, the researcher has developed two validity questionnaires. They are Content Validity Questionnaire for the English Teaching Efficacy Enhancement Module (MPEBI) for Early Childhood Education Teachers based on Russell (1974) and the Validity Questionnaire for the Content, Appropriate Strategy and Activity of the English Teaching Efficacy Enhancement Module (MPEBI) for Early Childhood Education Teachers based on Mohammad Aziz Shah (2010). The questionnaires were given to the module development experts to fill in the required information. This is to see the module content validity. Besides, the comments expressed by the experts can improve the quality of the module content before it gets to be implemented in the actual study. 
INTERNATIONAL JOURNAL OF ACADEMIC RESEARCH IN PROGRESSIVE EDUCATION AND DEVELOPMENT

Vol. 7, No. 4, 2018, E-ISSN: 2226-6348 @ 2018 HRMARS

The main goal of measuring content validity is to ensure that the items contained in the English Teaching Efficacy Enhancement Module (MPEBI) for Early Childhood Education Teachers represent areas that should be measured. In addition, the researcher can make an assumption whether there is a relationship between the module and the dependent variables. Two main assumptions of the study include: (1) The use of the module could improve the level of teacher efficacy in teaching English and (2) the use of the module can reduce the level of anxiety in teaching English.

\section{Research Methodology}

There are several processes to execute in order to determine the module content validity. Each module expert was given a set of activities contained in the English Teaching Efficacy Enhancement Module (MPEBI) for Early Childhood Education Teachers. The module experts were requested to fill in the Content Validity Questionnaire for the English Teaching Efficacy Enhancement Module (MPEBI) for Early Childhood Education Teachers based on Russell (1974) and the Validity Questionnaire for the Content, Appropriate Strategy and Activity of the English Teaching Efficacy Enhancement Module (MPEBI) for Early Childhood Education Teachers based on Mohammad Aziz Shah (2010). They were to provide comments, responses, feedback and suggestions regarding the suitability of the strategies, activities and the whole content of the module activities. Such viewpoints serve as ideas on how to strengthen and improve the module activity (Jamaludin Ahmad, 2016).

To determine whether a module has good content validity, Tuckman and Waheed (1981), as well as Abu Bakar Nordin (1995) believe that achieving 70 percent is considered to be high in achievement. Therefore, module activities which have been evaluated by experts were calculated using the following formula:

Expert's Total Score $(x)$

Maximum Score (y)
$\mathrm{X} 100=$ Content validity

Diagram 1: Content Validity Formula by Sidek \& Jamaludin (2005)

The total score given by the expert through the Likert scale was summed up $(x)$ and this score was divided by the maximum score of Likert scale and then multiplied by 100 . With the cutting point of 70 percent, any score above it indicates high content validity and vice versa.

\section{Research Methodology}

According to Mohammad Aziz Shah Mohamed Arip (2010), a module should be evaluated in terms of its content. As for Russell (1974), a module is to be assessed based on its activity execution: Whether it is appropriate for the target population, practical, in accordance with the time allocated, able to improve the English teaching efficacy and able to reduce the level of English teaching anxiety. A total of nine experts (comprising field experts and module development experts) were selected to evaluate the validity of this module. 
INTERNATIONAL JOURNAL OF ACADEMIC RESEARCH IN PROGRESSIVE EDUCATION AND

DEVELOPMENT

Vol. 7, No. 4, 2018, E-ISSN: 2226-6348 @ 2018 HRMARS

Table 1

Table 1: Evaluation of MPEBI by nine experts $(n=9)$ based on Russell's (1974) module validity

\begin{tabular}{|c|c|c|c|c|c|c|c|c|c|c|c|}
\hline Panels' Viewpoints & P1 & $\mathbf{P 2}$ & P3 & P4 & P5 & P6 & P7 & P8 & P9 & $\begin{array}{l}\text { Experts' } \\
\text { Percentage }\end{array}$ & Results \\
\hline $\begin{array}{l}\text { The content of this } \\
\text { module is } \\
\text { appropriate for the } \\
\text { target population }\end{array}$ & 10 & 9 & 7 & 7 & 10 & 9 & 8 & 8 & 8 & 84.4 & Accepted \\
\hline $\begin{array}{l}\text { The content of this } \\
\text { module can be } \\
\text { implemented } \\
\text { practically }\end{array}$ & 9 & 9 & 8 & 7 & 10 & 10 & 8 & 8 & 7 & 84.4 & Accepted \\
\hline $\begin{array}{l}\text { The content of this } \\
\text { module corresponds } \\
\text { with the time } \\
\text { allocated }\end{array}$ & 10 & 10 & 8 & 8 & 10 & 8 & 8 & 8 & 7 & 85.5 & Accepted \\
\hline $\begin{array}{l}\text { The content of this } \\
\text { module can improve } \\
\text { knowledge in the } \\
\text { efficacy of teachers } \\
\text { teaching English }\end{array}$ & 10 & 9 & 7 & 8 & 10 & 10 & 7 & 8 & 9 & 86.6 & Accepted \\
\hline $\begin{array}{l}\text { The content of this } \\
\text { module can reduce } \\
\text { the level of anxiety } \\
\text { of teachers teaching } \\
\text { English }\end{array}$ & 9 & 9 & 7 & 8 & 9 & 8 & 7 & 8 & 9 & 82.2 & Accepted \\
\hline $\begin{array}{l}\text { Total content } \\
\text { validity of MEPBI }\end{array}$ & & & & & & & & & & 84.6 & Accepted \\
\hline
\end{tabular}


INTERNATIONAL JOURNAL OF ACADEMIC RESEARCH IN PROGRESSIVE EDUCATION AND

DEVELOPMENT

Vol. 7, No. 4, 2018, E-ISSN: $2226-6348$ @ 2018 HRMARS

Table 2 : Comments, suggestions, actions and improvements for the MPEBI by nine experts

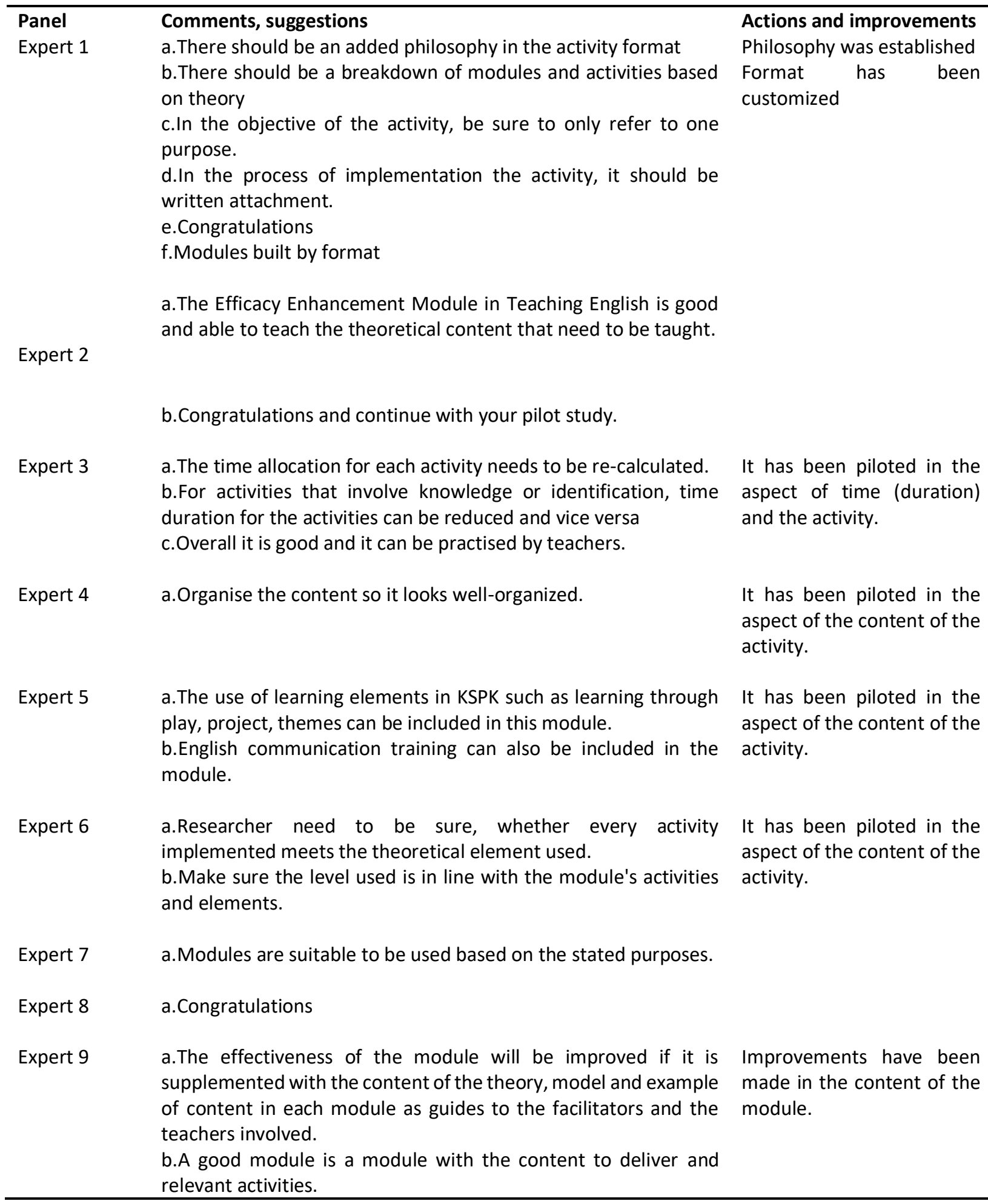


INTERNATIONAL JOURNAL OF ACADEMIC RESEARCH IN PROGRESSIVE EDUCATION AND

DEVELOPMENT

Vol. 7, No. 4, 2018, E-ISSN: 2226-6348 (C) 2018 HRMARS

Table 3 : The Validity of the Content of the Module based on the Activity According to Mohammad Aziz Shah (2010) By Nine Expert Panel

\begin{tabular}{|c|c|c|c|c|c|c|c|c|c|c|c|}
\hline Sub Module / Activity & P1 & $\mathbf{P 2}$ & P3 & P4 & P5 & P6 & P7 & P8 & P9 & $\begin{array}{l}\text { Experts' } \\
\text { Percentages }\end{array}$ & $\begin{array}{l}\text { Experts' } \\
\text { Viewpoints }\end{array}$ \\
\hline 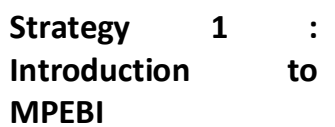 & & & & & & & & & & & \\
\hline $\begin{array}{lrr}\text { Activity } & 1 & \text { : } \\
\text { Recognising } & \text { the } \\
\text { Bandura's } & \text { Self- } \\
\text { Efficacy Theory } & \end{array}$ & 7 & 9 & 7 & 6 & 9 & 9 & 8 & 8 & 8 & 78.8 & Accepted \\
\hline $\begin{array}{l}\text { Aktivity } 2: \text { Self- } \\
\text { empowerment }\end{array}$ & 7 & 10 & 8 & 7 & 9 & 8 & 8 & 9 & 8 & 82.2 & Accepted \\
\hline $\begin{array}{lr}\text { Strategy } \quad 2 & : \\
\text { Knowledge } & \text { and } \\
\text { Achievement } & \text { in } \\
\text { English Language } & \end{array}$ & & & & & & & & & & & \\
\hline $\begin{array}{l}\text { Activity } 1 \text { : Reaching } \\
\text { for the stars } \\
\text { Activity } 2: \text { Pedagogy }\end{array}$ & 9 & 8 & 8 & 7 & 10 & 9 & 8 & 9 & 8 & 84.4 & Accepted \\
\hline $\begin{array}{l}\text { Knowledge of English } \\
\text { Pedagogy } \\
\text { Activity 3: } \\
\text { Past Teaching }\end{array}$ & 9 & 9 & 8 & 8 & 9 & 10 & 7 & 9 & 8 & 85.5 & Accepted \\
\hline $\begin{array}{l}\text { Performance } \\
\text { Activity } 4 \text { : } \\
\text { Knowledge of content }\end{array}$ & 9 & 10 & 8 & 8 & 9 & 9 & 8 & 9 & 8 & 86.6 & Accepted \\
\hline Strategy 3 : Self- & 9 & 9 & 8 & 8 & 9 & 9 & 7 & 9 & 8 & 84.4 & Accepted \\
\hline $\begin{array}{l}\text { Activity } 1: \text { : My } \\
\text { Guiding Buddy }\end{array}$ & & & & & & & & & & & \\
\hline $\begin{array}{l}\text { Activity } 2: \text { My } \\
\text { Mentor }\end{array}$ & & & & & & & & & & & \\
\hline $\begin{array}{l}\text { Activity } 3: \text { I Am A } \\
\text { Champion }\end{array}$ & 9 & 9 & 8 & 9 & 10 & 9 & 8 & 9 & 8 & 87.7 & Accepted \\
\hline $\begin{array}{l}\text { Activity } 4: \text { : Let's } \\
\text { Practice }\end{array}$ & 9 & 10 & 8 & 9 & 10 & 10 & 7 & 8 & 8 & 87.7 & Accepted \\
\hline Strategy $4:$ Self- & 7 & 9 & 8 & 8 & 10 & 9 & 8 & 9 & 8 & 84.4 & Accepted \\
\hline $\begin{array}{l}\text { Assessment } \\
\text { Teaching } \\
\text { Activity 1 : } \\
\text { Critics } \\
\text { Activity 2 : } \\
\text { Teaching }\end{array}$ & 8 & 9 & 8 & 8 & 9 & 8 & 8 & 9 & 8 & 83.3 & Accepted \\
\hline $\begin{array}{l}\text { Activity } 3 \text { : Let's Write } \\
\text { Lesson Plan }\end{array}$ & 7 & 10 & 8 & 8 & 9 & 10 & 8 & 9 & 8 & 85.5 & Accepted \\
\hline & 8 & 9 & 8 & 8 & 10 & 9 & 7 & 9 & 8 & 84.4 & Accepted \\
\hline
\end{tabular}




\section{INTERNATIONAL JOURNAL OF ACADEMIC RESEARCH IN PROGRESSIVE EDUCATION AND}

DEVELOPMENT

Vol. 7, No. 4, 2018, E-ISSN: 2226-6348 @ 2018 HRMARS

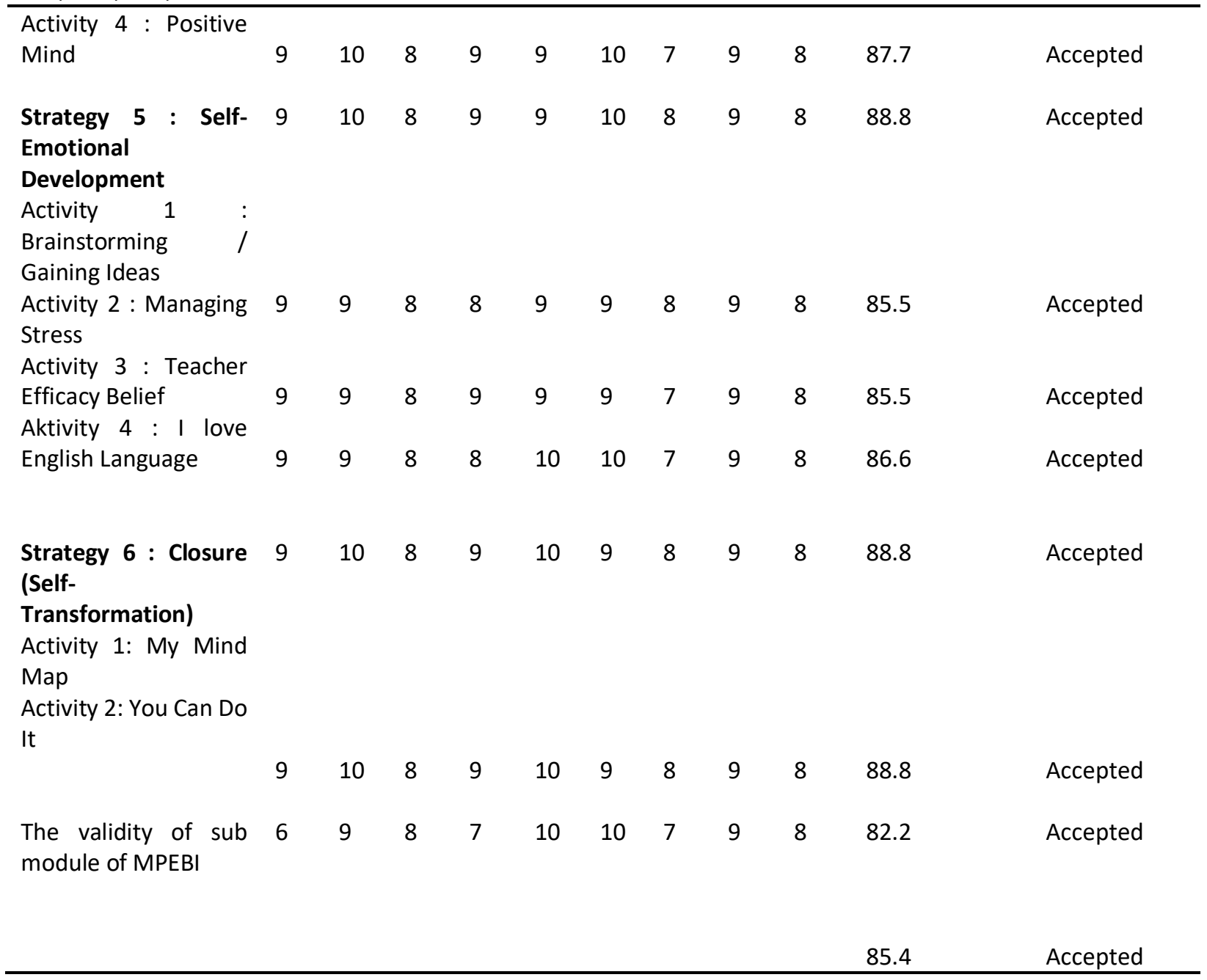


INTERNATIONAL JOURNAL OF ACADEMIC RESEARCH IN PROGRESSIVE EDUCATION AND

DEVELOPMENT

Vol. 7, No. 4, 2018, E-ISSN: $2226-6348$ @ 2018 HRMARS

Table 4 : Comments, suggestions, actions and improvements for the sub module of MPEBI by nine experts

\begin{tabular}{|c|c|}
\hline Panel & Comments, suggestions \\
\hline Expert 1 & $\begin{array}{l}\text { a.Good and appropriate } \\
\text { b.The Efficacy Enhancement Module in Teaching English is good and able } \\
\text { to deliver teaching based on the Bandura's self-efficacy theory that the } \\
\text { researcher wishes to study. } \\
\text { c.Congratulations and continue your pilot study. }\end{array}$ \\
\hline Expert 2 & $\begin{array}{l}\text { a.Exciting activities. You just need to add appropriate graphics. } \\
\text { b.Sentences in the questions of the activity need to be closer to the } \\
\text { targeted audience. } \\
\text { c.For knowledge activities, it is necessary to give notes about the English } \\
\text { Language pedagogy as in line with the Ministry of Education. } \\
\text { d.Participants should be provided with a note on efficacy knowledge } \\
\text { before answering self-training in the module. } \\
\text { e.Well, just some of the activities in the module need to be refined and } \\
\text { improved the form of activity. }\end{array}$ \\
\hline
\end{tabular}

\section{Actions \\ improvements}

Pilot study was conducted in April 2018

It has been piloted in the aspect of the content of the activity

Notes to module users are provided in the form of slides.

Expert 3 a.There is no clear description on how facilitators should execute the activity.

A note to the facilitator as a guide to running a module b. The use of the term expert or teacher should be consistent.

c. Need to think of the time allocated to answer the exercise. is provided

d.Suggested answers in graphic form so that teachers do not take long time to answer.

Expert 4 a.There should be elements of the National Preschool Standard Curriculum because it involves the correct way of teaching preschool. b. Need to look at the elements in preschool. c.Need to add English Language teaching and learning videos.

Expert 5 a.Activity can be improved, not just listing activity alone.

b.Encourage the use of high level thinking skills.

c. The design of the activity needs to be more concrete.

d.Overall, the module activity is appropriate, maybe improvements on the activities can be made.

Expert 6 a.The module is very impressive. Congrats!!

b.It is uncertain whether this module can improve teachers' efficacy.

c.Efficacy is triggered by the availability of English language skills and is achieved through language training.

Video on how to teach English are provided.

It has been piloted in the aspect of the content of the activity

The main objective of the module is to increase knowledge in the efficacy of teaching English Language.

Expert $7 \quad$ a.Good and well-organised module design. 


\begin{tabular}{|c|c|c|}
\hline Expert 8 & $\begin{array}{l}\text { a.Review some technical errors (spelling and punctuation) } \\
\text { b.The activity guide box should have a purpose and its function is not } \\
\text { clear. } \\
\text { c.Objectives need to be explicit } \\
\text { d.Question } 1 \text { on Managing Stress Form is too much, needs to be } \\
\text { breakdown. } \\
\text { e.This module is seen only as a form of introduction to self efficacy. If you } \\
\text { really want to improve the self-efficacy, the module should include } \\
\text { training or coaching in (on-job training) } 3 \text { to } 6 \text { months, only then you can } \\
\text { improve the self-efficacy of teachers in teaching English Language. }\end{array}$ & $\begin{array}{l}\text { It has been piloted in } \\
\text { the aspect of the } \\
\text { content of the activity } \\
\text { The main objective of } \\
\text { the module is to } \\
\text { increase knowledge } \\
\text { in the efficacy of } \\
\text { teaching English } \\
\text { Language. }\end{array}$ \\
\hline \multirow[t]{3}{*}{ Expert 9} & $\begin{array}{l}\text { a.For strategy 2, there should be additional types of teaching methods in } \\
\text { English Language, the content of effective English preschool teaching and } \\
\text { learning features and short English content in the diagram. } \\
\text { b.For strategy } 3 \text {, it should include the content of good and effective }\end{array}$ & $\begin{array}{l}\text { It has been piloted in } \\
\text { the aspect of the } \\
\text { content of the activity }\end{array}$ \\
\hline & $\begin{array}{l}\text { guiding buddy, the content of good and effective mentor features and } \\
\text { the content of some English Language teaching and learning strategies. } \\
\text { c.For strategy } 4 \text {, it is necessary to include a sample content of teacher } \\
\text { teaching assessment tool, a good example of good micro teaching and an }\end{array}$ & $\begin{array}{l}\text { Facilitators' notes } \\
\text { need to be improved } \\
\text { as expert advice }\end{array}$ \\
\hline & $\begin{array}{l}\text { example of a good daily lesson plan. } \\
\text { d. For strategy 5, it is needed to add examples of activities that can help } \\
\text { teachers generate ideas and the content of pressure factors for teachers. } \\
\text { e.Overall, it is recommended that researcher add the proposed content }\end{array}$ & $\begin{array}{l}\text { The module explains } \\
\text { some interesting } \\
\text { English teaching } \\
\text { methods. }\end{array}$ \\
\hline
\end{tabular}

\section{Conclusion}

In conclusion, the module content validity is an effort to measure whether the activity content, delivery and strategies suit the target population. Besides, it is also to ensure the module usability in enhancing the English teaching efficacy and reducing the level of anxiety of English teachers. This shows how important it is to determining the validity of a module before it can be used by the module users.

\section{Corresponding Author}

Nur Nazuha Beevi Abdul Aziz

National Child Development Research Centre

Sultan Idris Education University, 35900 Tanjong Malim

Perak, Malaysia

Email: bibiyana_aziz@yahoo.com

\section{References}

Abdul Aziz, N.N.B. \& Mamat, N. (2015). Efikasi Kendiri Guru dan Hubungannya Dengan Pencapaian Akademik Di Sekolah. Prosiding Seminar Kebangsaan Pascasiswazah Asuhan dan Didikan Kanak-Kanak. Tanjong Malim : Universiti Pendidikan Sultan Idris.

Abdul Aziz, N.N.B. \& Mamat, N. (2015). Pembinaan Modul Efikasi Pengajaran dan Pembelajaran Bahasa Inggeris Prasekolah Dalam Meningkatkan Tahap Efikasi Guru dan Tahap Penguasaan Kosa Kata Bahasa Inggeris di Kalangan Kanak-Kanak Prasekolah. Prosiding 
INTERNATIONAL JOURNAL OF ACADEMIC RESEARCH IN PROGRESSIVE EDUCATION AND

DEVELOPMENT

Vol. 7, No. 4, 2018, E-ISSN: 2226-6348 @ 2018 HRMARS

Seminar Penyelidikan Pendidikan Kebangsaan IPG Kampus Zon Utara 2015. Pulau Pinang : Institut Pendidikan Guru Tuanku Bainun.

Abdul Aziz, N.N.B. \& Mamat, N. (2017). Pembangunan Modul Peningkatan Efikasi Mengajar Bahasa Inggeris Guru Prasekolah (MEP-BI) : Kajian Rintis. Prosiding Seminar Pascasiswazah Kebangsaan 2017. Tanjong Malim : Universiti Pendidikan Sultan Idris.

Abdul Aziz, N.N.B \& Mamat, N. (2017). Analisis Keperluan : Pembangunan Modul Efikasi Pengajaran Bahasa Inggeris Guru Prasekolah. Proceedings National Conference on Education Social Science, Engineering and Technology (NCESET 2017). Kedah : Association of Malaysian Researchers \& Social Services (AMRASS).

Abdul Aziz, N.N.B. \& Mamat, N. (2017). Kesahan dan Kebolehpercayaan Soal Selidik Efikasi Pengajaran Bahasa Inggeris Dalam Kalangan Guru Prasekolah. Prosiding Seminar Wacana Pendidikan 2017 (SWAPEN). Kedah : Institut Pengurusan dan Integriti.

Abdul Aziz, N.N.B. \& Mamat, N. (2018). Kajian Reka Bentuk dan Pembangunan Modul Peningkatan Efikasi Mengajar Bahasa Inggeris (MPEBI) Guru Prasekolah. International Conference On The Future Of Education (IConFED). Pulau Pinang : Hotel Bayview.

Abdul Aziz, N.N.B. \& Mamat, N. (2018). Modul Peningkatan Efikasi Mengajar Bahasa Inggeris (MPEBI) Guru Pendidikan Awal Kanak-Kanak : Kajian Rintis. International Conference On Teacher Learning And Develoment (ICTLD). Kuala Lumpur : Hotel Royale Chulan.

Abdul Rahman, M.N. (2016). Application of Fuzzy Delphi Approach in Designing Homeschooling Education for Early Childhood Islamic Education. Tesis PhD. Kuala Lumpur : Universiti Malaysia.

Bandura, A. (1997). Self-Efficacy : The exercise of control. New York : Freeman.

Johari, K., Ismail, Z., Osman, S., \& Othman, Tajuddin. (2009). Pengaruh jenis latihan guru dan pengalaman mengajar terhadap efikasi guru sekolah menengah. Jurnal Pendidikan Malaysia. 34 (2), 3-14.

Kementerian Pelajaran Malaysia. (2009). Dokumen standard prasekolah : Kurikulum Standard Prasekolah Kebangsaan. Kuala Lumpur : Bahagian Pembangunan Kurikulum, Kementerian Pelajaran Malaysia.

Mohamed Arip, M. A. S. (2010). Kesan kelompok bimbingan terapi kognitif-tingkahlaku ke atas konsep kendiri, kelangsangan dan daya tahan remaja. Tesis PhD, Fakulti Pendidikan, Universiti Kebangsaan Malaysia.

Mohamed Arip, M. A. S. (2018). Pembinaan dan Pengujian Modul. Selangor : I Psychology and Counseling Academy. 
INTERNATIONAL JOURNAL OF ACADEMIC RESEARCH IN PROGRESSIVE EDUCATION AND

DEVELOPMENT

Vol. 7, No. 4, 2018, E-ISSN: 2226-6348 @ 2018 HRMARS

Mohd Noah, S. (2005). Pengujian dan Penilaian Kaunseling : Teori dan Aplikasi. Serdang : Universiti Putra Malaysia.

Mohd Noah, S. \& Ahmad, J. (2005).Pembinaan Modul. Bagaimana membina modul latihan dan modul akademik. Serdang: Penerbit UPM.

Richey, R.C., \& Klein, J.D. (2007). Design and developmental research. New York, NY : Routledge.

Siraj, S., Alias, N., Dewitt, D., \& Hussin, Z. (2013). Design and developmental research : Emergent trends in educational research. Kuala Lumpur : Pearson Malaysia.

Thompson. G. (2016). Japanese High School English Teachers' Self-Efficacy Beliefs About Teaching English. PhD Theses, Faculty of Education : Queensland University of Technology.

Tschannen-Moran, M., \& Woolfolk Hoy, A. (2001). Teacher efficacy : Capturing and elusive construct. Teaching and Teacher Education, 17, 783 - 805. 